\title{
ANALISIS UPAYA GURU DALAM MEMOTIVASI SISWA PADA PROSES PEMBELAJARAN SOSIOLOGI KELAS XI IPS2
}

\author{
Berry \\ SMA Wisuda Pontianak \\ E-mail: Berryumar@gmail.com
}

\begin{abstract}
The title of this research is "Analysis of Teacher Efforts to Manage Students in the Learning Process IPS2 Sociology Class XI". The purpose of this study was to determine and describe the efforts of teachers to motivate students in the learning process IPS2 sociology class XI. The approach used in this study is a qualitative approach with descriptive methods. The process of implementation is carried out with test instruments such as observation, interviews, and documentation.

The results showed that the efforts of teachers to motivate students in the learning process of sociology in general have been implemented but have not carried out to the maximum. Constraints implementation of motivation by teachers, teacher attendance factors and methods of teaching, the student's social environment, and infrastructure are less supportive. The response of students is very worth noting that the way teachers deliver the material time in the classroom, because the volume is not loud teachers.
\end{abstract}

Keywords: Effort Teacher, Motivate, Learning Process 
Dalam penyelenggaraan pendidikan di sekolah yang melibatkan guru sebagai pendidik dan siswa sebagai peserta didik, diwujudkan dengan adanya interaksi yang baik sehingga dapat memberikan motivasi dalam proses pembelajaran agar bisa berjalan sebagaimana mestinya. Pendidikan pada dasarnya adalah usaha sadar untuk menumbuhkembangkan potensi sumber daya manusia peserta didik dengan cara mendorong dan memfasilitasi kegiatan belajar mereka.

Salah satunya dengan memberikan motivasi kepada siswa dalam proses pembelajaran. Dengan memberikan motivasi berarti menggerakkan siswa untuk melakukan sesuatu atau ingin melakukan sesuatu. Pada tahap awalnya akan menyebabkan si subjek belajar merasa ada kebutuhan dan ingin melakukan sesuatu kegiatan belajar. Hal ini sejalan dengan pendapat Mc. Donald (Sardiman 2008: 74), motivasi adalah perubahan energi dalam diri seseorang yang ditandai dengan munculnya "feeling" dan didahului dengan tanggapan terhadap adanya tujuan.

Dalam kegiatan belajar, motivasi dapat dikatakan sebagai keseluruhan daya penggerak di dalam diri siswa yang menimbulkan kegiatan belajar, yang menjamin kelangsungan dari kegiatan belajar dan yang akan memberikan arah pada kegiatan belajar, sehingga tujuan yang dikehendaki oleh subjek belajar itu dapat tercapai. Sardiman (2008:75), berpendapat bahwa motivasi dapat juga dikatakan serangkaian usaha untuk menyediakan kondisi-kondisi tertentu, sehingga seseorang mau dan ingin melakukan sesuatu, dan bila ia tidak suka maka akan berusaha untuk meniadakan atau mengelakkan perasaan tidak suka itu.
Oleh karena itu guru sebagai salah satu unsur dibidang kependidikan harus berperan serta secara aktif dan menempatkan kedudukannya sebagai tenaga professional sesuai tuntutan masyarakat yang semakin berkembang. Dalam arti khusus dapat dikatakan bahwa pada setiap diri guru itu terletak tanggung jawab untuk membawa para siswanya pada suatu kedewasaan atau taraf kematangan tertentu. Oleh karena itu guru harus dapat memotivasi siswanya dalam pembelajaran agar sesuatu yang diharapkan dapat tercapai sebagaimana mestinya.

Salah satu mata pelajaran yang ada di Sekolah Menengah Atas adalah mata pelajaran Sosiologi. Pembelajaran sosiologi dimaksudkan untuk mengembangkan

kemampuan pemahaman siswa tentang fenomena kehidupan sehari-hari. Materi pelajaran mencakup konsep-konsep dasar, pendekatan, metode, dan teknik analisis dalam pengkajian berbagai fenomena dan permasalahan yang ditemui dalam kehidupan nyata di masyarakat.

Berdasarkan prariset yang dilakukan di kelas XI IPS2, pada kegiatan awal proses pembelajaran berlangsung guru melakukan apersepsi dan memberikan motivasi kepada siswa dengan cara menjelaskan tujuan pembelajaran yang akan dipelajari dan menggali pengetahuan awal siswa tentang topik yang akan dibahas melalui pertanyaan lisan. Masuk pada kegiatan inti guru memberikan penegasan konsep tentang topik yang sedang dibahas dengan menggunakan metode ceramah dan tanya jawab, dan pada kegiatan akhir guru bersama siswa menyimpulkan topik yang telah dibahas serta memberikan pertanyaan kepada 
siswa secara lisan dan tertulis sebagai bentuk post tes.

Namun sangat jelas terlihat siswa yang termotivasi dan siswa yang kurang termotivasi dalam mengikuti kegiatan pembelajaran sosiologi. Hal ini tampak ketika guru sedang menyampaikan materi pelajaran di depan kelas, siswa yang termotivasi selalu mendengarkan dan bertanya jawab ketika ada yang kurang jelas saat proses pembelajaran berlangsung. Namun ketika melihat siswa yang kurang termotivasi mereka lebih terlihat bosan saat mengikuti pelajaran, malu bertanya, bahkan siswa yang tidak

\section{METODE}

Pendekatan yang digunakan dalam penelitian ini adalah pendekatan kualitatif dengan metode deskriptif. Pendekatan kualitatif diartikan sebagai sebuah pendekatan yang berorientasi secara ilmiah, proses pelaksaannya dilakukan dengan instrument tes seperti, observasi, wawancara, dan studi dokumentasi.

Bentuk penelitian ini adalah penelitian deskriptif, hal ini sesuai dengan pendapat Hadari Nawawi (1992:67), bahwa penelitian deskriptif adalah prosedur atau cara memecahkan masalah penelitian dengan memaparkan keadaan objek yang diselidiki (seseorang, lembaga, masyarakat, pabrik dan lain-lain) sebagaimana adanya, berdasarkan faktafakta yang aktual pada saat sekarang.

Data dalam sebuah penelitian, merupakan bahan pokok yang dapat diolah dan dianalisis untuk menjawab masalah penelitian. Menurut Suharsimi Arikunto (2010:172) menyatakan, "sumber data dalam penelitian adalah subjek dari mana data dapat diperoleh". Adapun yang menjadi sumber data primer dalam penelitian ini adalah guru mata pelajaran sosiologi kelas XI IPS2 dan siswa kelas XI IPS2. Sedangkan data sekunder dalam aktif mereka lebih tertarik untuk ngobrol dengan teman sebangku, mengganggu teman, bermain handphone, keluar masuk kelas, tiduran, sehingga tidak memperdulikan guru yang sedang menyampaikan materi pelajaran di depan kelas.

Dengan melihat gejala di atas, maka peneliti terdorong untuk melakukan penelitian mengenai "Analisis Upaya Guru dalam Memotivasi Siswa pada Proses Pembelajaran Sosiologi Kelas XI IPS2”.

penelitian ini berasal dari arsip-arsip yang dimiliki sekolah dan guru.

Dalam setiap penelitian untuk menjawab permasalahan yang ada dalam penelitian diperlukan teknik dan alat pengumpul data yang tepat. Hadari Nawawi (1983:100-101) mengatakan bahwa ada beberapa teknik dan alat pengumpul data, yaitu teknik observasi langsung, teknik komunikasi langsung dan teknik studi dokumenter.

Dalam penelitian ini, pengujian keabsahan data menggunakan teknik Triangulasi. Menurut Sugiyono (2013:83) menyatakan bahwa, triangulasi diartikan sebagai "teknik pengumpulan data yang bersifat menggabungkan dari berbagai teknik pengumpulan data dan sumber data yang telah ada". Sehubungan dengan teknik pengelolaan data maka peneliti merencanakan berdasarkan jenis data yang diperoleh selama di lapangan. Untuk jenis data yang diperoleh berdasarkan observasi dan wawancara dilakukan dengan mengacu kepada panduan observasi dan panduan wawancara yang akan dikembangkan. Hasil dari pengamatan data seperti daftar cek, daftar observasi,dan wawancara diolah dengan mendeskripsikan secara kualitatif 
sebagaimana fakta yang ditemukan di lapangan. Sedangkan dokumen/arsip digunakan untuk mendukung dan melengkapi deskripsi sebelum diolah dengan penelitian triangulasi.

\section{HASIL PENELITIAN DAN PEMBAHASAN Hasil Penelitian}

Tabel 1

Identitas Informan (Nama Inisial)

\begin{tabular}{ccc}
\hline No & Nama Informan & Keterangan \\
\hline 1 & NA & Guru mata pelajaran sosiologi \\
\hline 2 & AA & Siswi kelas XI IPS2 \\
\hline 3 & AM & Siswa kelas XI IPS2 \\
\hline 4 & KR & Siswi kelas XI IPS2 \\
\hline 5 & MR & Siswa kelas XI IPS2 \\
\hline 6 & RG & Siswa kelas XI IPS2 \\
\hline 7 & SM & Siswi kelas XI IPS2 \\
\hline
\end{tabular}

Keterangan: Data Olahan Tahun 2015

Data observasi dalam penelitian ini diperoleh dari hasil pengamatan yang dilakukan peneliti sebanyak 4 kali dimana setiap kali pertemuan peneliti selalu melakukan pengamatan secara cermat dan objektif terhadap keadaan yang terkait dengan penelitian yang peneliti lakukan khususnya mengamati guru dalam memotivasi siswa pada proses pembelajaran. Adapun data yang diperoleh sebagai berikut, dalam aspek memberikan angka (penilaian), selama observasi guru sosiologi hanya satu kali memberikan angka (penilaian) kepada siswa yaitu pada observasi pertama saja, namun pada observasi selanjutnya guru sosiologi tidak memberikan angka lagi. Peneliti juga melihat guru langsung mengurangi nilai kepada siswa yang tidak mau mengerjakan tugas, siswa yang ribut dan siswa yang tidak mau mendengarkan guru yang sedang menjelaskan saat proses pembelajaran berlangsung. Karena penilaian yang diberikan ditinjau dari tiga aspek, yaitu aspek pengetahuan, keterampilan dan sikap siswa.

Selanjutnya dalam aspek memberikan hadiah atau pujian, guru sosiologi tidak memberikan motivasi dalam bentuk hadiah, namun memberikan pujian dan applause kepada siswa yang mendapatkan nilai dan prestasi bagus dalam pembelajaran sosiologi. Disini siswa yang mendapatkan nilai baik mereka terlihat begitu senang dan puas dengan hasil yang didapat dan bersemangat untuk mempertahankan nilainya. Bagi siswa yang nilainya belum tuntas terlihat kecewa dan kesal dengan nilai yang didapatnya.

$$
\text { Kemudian dalam aspek }
$$
memberikan ulangan, pada observasi kedua guru sosiologi memberikan ulangan harian kepada siswa sebanyak 10 soal dalam bentuk essay. Peneliti melihat keseriusan siswa saat mengisi soal ulangan, namun masih ada siswa yang duduk dibangku belakang membuka buku catatan, dan mencontek teman sebangku. 
Sementara itu pada aspek memberitahukan hasil yang didapat, selama observasi guru mata pelajaran sosiologi hanya dua kali memberitahukan hasil yang didapat siswa, yaitu memberitahukan hasil tugas di rumah pada observasi kedua dan memberitahukan hasil ulangan pada observasi ketiga. Peneliti melihat setiap guru memberitahukan hasil, siswa yang mendapat nilai baik terlihat merasa sangat senang dan bersemangat dalam mengikuti pelajaran, sedangkan siswa yang mendapatkan nilai kurang baik terlihat merasa kecewa dengan hasil yang sudah didapat.

Pada aspek tujuan yang diakui, selama observasi peneliti melihat bahwa guru mata pelajaran sosiologi menyampaikan tujuan pembelajaran pada pertemuan sesudah diadakan ulangan harian saja. Namun pada pertemuan sebelum diadakan ulangan harian dan pertemuan kedua setelah diadakan ulangan harian, guru mata pelajaran sosiologi tidak menyampaikan tujuan pembelajaran lagi kepada siswanya.

Kendala pelaksanaan pemberian motivasi oleh guru pada proses pembelajaran sosiologi di kelas XI IPS2. Hal ini terlihat selama observasi berlangsung, peneliti mengamati sub-sub aspek dari aspek penelitian ini. Selama observasi berlangsung peneliti mengamati proses pembelajaran, seperti kehadiran dan keterampilan mengajar guru sosiologi, lingkungan sosial (teman sebaya) siswa, kurikulum dan sarana prasarana.

Dalam aspek kehadiran guru dan keterampilan mengajar, selama pengamatan guru mata pelajaran sosiologi selalu hadir, namun sering terlambat untuk masuk kelas karena ada urusan lain di ruang Wakil Kepala sekolah. Hanya satu kali saja guru datang tepat waktu yaitu pada observasi kedua karena pada hari tersebut guru mata pelajaran sosiologi memberikan ulangan harian kepada siswa. Peneliti melihat jika guru mata pelajaran sosiologi terlambat masuk kelas, siswa lebih memilih pergi ke kantin, dudukduduk di teras kelas, dan ribut tanpa ada yang mengontrol. Mengenai keterampilan mengajar, selama pengamatan guru selalu menyampaikan materi dengan metode ceramah, memberikan latihan di dalam LKS, membaca dan menjawab soal diLKS kemudian apabila siswa tersebut tidak bisa menjawab, guru dan siswa lainnyalah yang menjawab secara bersama-sama untuk meluruskan jawabannya. Saat guru menjelaskan materi di depan kelas, tidak jarang siswa ngobrol dengan teman sebangku, tiduran, main hp, karena guru tidak selalu mengontrol siswa yang duduk dibarisan belakang, guru selalu menjelaskan hanya dengan duduk dikursinya saja.

Selanjutnya dalam aspek lingkungan sosial (teman sebaya), peneliti melihat pengaruh teman sebaya sangat kuat terhadap motivasi belajar siswa. Siswa yang sebelumnya mendengarkan guru menjelaskan tiba-tiba diajak teman sebelah berbicara, maka langsung ikut bicara, ikut-ikutan mengganggu teman lainnya sehingga siswa yang pada awalnya fokus mengikuti pelajaran setelah diganggu temannya jadi kehilangan konsentrasi untuk belajar. Apalagi gurunya yang tidak selalu mengontrol sampai ke belakang kelas saat mengajar, sehingga siswa lebih leluasa untuk mengganggu teman, bermain handphone, berbicara dan lain sebagainya.

Kemudian dalam aspek kurikulum sekolah, sekolahan ini sudah menggunakan kurikulum 2013 sejak tahun 2013, karena menjadi sekolahan uji coba penggunaan kurikulum 2013 pada tahun tersebut hingga sekarang. Selama proses 
pembelajaran peneliti melihat bahwa guru mata pelajaran sosiologi selalu menggunakan metode ceramah dan tanya jawab kepada siswa.

Selanjutnya aspek sarana dan prasarana, peneliti melihat adanya pengaruh besar antara sarana prasarana terhadap motivasi belajar siswa. Di kelas XI IPS2 memiliki 2 buah kipas angin namun tidak bisa difungsikan, pentilasi yang kurang baik sehingga sirkulasi udara kurang baik pula. Apalagi lokasi kelas XI IPS2 ini berdekatan dengan WC yang baunya terkadang menyengat hingga ke dalam kelas. Hal ini tentu menjadi kendala dalam pemberian motivasi guru kepada siswanya saat proses pembelajaran.

\section{Pembahasan}

Dalam kegiatan belajar mengajar peranan motivasi baik intrinsik maupun ekstrinsik sangat diperlukan. Dengan motivasi, pelajar dapat mengembangkan aktivitas dan inisiatif, dapat mengarahkan dan memelihara ketekunan dalam melakukan kegiatan belajar.

Dalam kaitannya itu perlu diketahui bahwa cara dan jenis menumbuhkan motivasi ada bermacam-macam. Tetapi untuk motivasi ekstrinsik kadang-kadang tepat, dan kadang juga bisa kurang sesuai. Dalam hai ini guru sebaiknya berhati-hati dalam menumbuhkan dan memberikan motivasi bagi kegiatan belajar para siswa. Sebab mungkin maksudnya memberikan motivasi tetapi justru tidak menguntungkan perkembangan belajar siswa.

Sebagaimana yang diungkapkan Sardiman (2008:92), ada beberapa bentuk dan cara untuk menumbuhkan motivasi dalam kegiatan belajar siswa di sekolah diantaranya memberi angka, hadiah dan
Kemudian mengenai tanggapan siswa terhadap pemberian motivasi guru pada proses pembelajaran sosiologi ratarata siswa mengatakan bahwa guru mata pelajaran sosiologi pernah memberikan angka, memberikan pujian, memberikan ulangan, memberitahukan hasil dan tujuan yang diakui. Namun tidak dilakukan secara maksimal. Tanggapan dari siswa yang sangat perlu diperhatikan yakni mengenai cara guru menyampaikan materi saat di dalam kelas, siswa mengatakan kurang mengerti tentang materi yang disampaikan oleh guru sosiologi karena volume suara guru yang tidak keras. Hal ini membuat siswa malas mengikuti pelajaran sosiologi

pujian, memberi ulangan, mengetahui hasil, dan tujuan yang diakui.

Dari hasil pengamatan kepada guru mata pelajaran sosiologi kelas XI IPS2 mengenai upaya guru dalam memotivasi siswa pada proses pembelajaran sosiologi yakni dalam hal memberi angka/penilaian. Selama pengamatan, guru mata pelajaran sosiologi hanya satu kali memberikan angka/penilaian kepada siswa yakni ketika siswa bisa menjawab pertanyaan lisan yang diberikan. Sedangkan menurut paparan guru mata pelajaran sosiologi itu sendiri bahwa beliau selalu memberikan angka kepada siswa berdasarkan tiga aspek yakni aspek pengetahuan, keterampilan dan sikap. Tetapi kenyataan di lapangan bahwa guru sosiologi hanya sekali saja memberikan angka kepada siswanya. Padahal dengan selalu memberikan angka akan membuat siswa termotivasi untuk selalu mendapatkan nilai baik. Sebagaimana dengan pendapat Sardiman (2008:92), "angka dalam hal ini sebagai simbol dari nilai kegiatan belajarnya". Banyak siswa belajar, yang utama justru untuk mencapai nilai/angka 
yang baik, sehingga yang biasanya dikejar siswa adalah nilai ulangan atau nilai raport angkanya baik-baik. Angka-angka yang baik itu bagi para siswa merupakan motivasi yang sangat kuat.

Kemudian dalam hal memberi hadiah atau pujian, guru mata pelajaran sosiologi kelas XI IPS2 tidak pernah memberikan hadiah, namun selalu memberikan pujian kepada siswa yang bisa menjawab pertanyaan yang diberikan, dari nilai tugas dan ulangan yang nilainya baik, dengan harapan agar siswa bisa berlomba-lomba untuk mendapatkan prestasi untuk mengharapkan hadiah/ pujian. Sesuai dengan penuturan beliau bahwa beliau tidak memberikan motivasi dalam bentuk hadiah, namun dalam bentuk pujian, penghargaan. Hal ini sejalan dengan pendapat Kenneth (dalam Hamalik 2013), "pujian lebih efektif dari pada hukuman. Hukuman bersifat menghentikan suatu perbuatan, sedangkan pujian bersifat menghargai apa yang telah dilakukan". Oleh karena itu, pujian lebih efektif dalam upaya mendorong motivasi belajar siswa.

Pada aspek memberikan ulangan, guru mata pelajaran sosiologi mengadakan ulangan harian sebanyak 10 soal dalam bentuk essay. Pada pertemuan sebelumnya guru sudah memberitahukan kepada siswa kalau pertemuan selanjutnya akan diadakan ulangan dan menyuruh siswa mengulangi pelajaran di rumah. Sesuai dengan penuturan beliau mata pelajaran sosiologi selalu memberikan ulangan harian perkompetensi dasar, karena sudah terprogram dari sekolah seperti ulangan harian pertama, ulangan harian kedua, ulangan tengah semester dan akhir semester. Hal ini sesuai dengan pendapat Sardiman (2008:93), "para siswa akan menjadi giat belajar kalau mengetahui akan ada ulangan”.
Begitu juga Menurut Muhibbin (2009:198), ada beberapa tujuan evaluasi dalam proses pembelajaran yaitu: 1) Untuk mengetahui kemajuan yang telah dicapai oleh siswa dalam suatu kurun waktu proses belajar tertentu; 2) Untuk mengetahui posisi atau kedudukan seorang siswa dalam kelompok kelasnya; 3) Untuk mengetahui tingkat usaha yang dilakukan siswa dalam belajar; 4) Untuk mengetahui hingga sejauh mana siswa telah menggunakan daya kognitifnya untuk keperluan belajar; dan 5) Untuk mengetahui tingkat daya guna dan hasil guna metode mengajar yang telah digunakan guru dalam proses belajar mengajar.

Oleh karena itu memberikan ulangan juga sarana motivasi. Peneliti melihat pada saat siswa mengikuti ulangan harian para siswa serius mengisi soal ulangan dengan harapan mendapatkan nilai yang bagus. Namun masih ada siswa yang duduk dikursi belakang membuka buku catatannya untuk mengisi ulangan harian yang diberikan.

Kemudian dalam aspek memberitahukan hasil yang didapat siswa, selama pengamatan peneliti melihat sebanyak dua kali pengamatan guru sosiologi memberitahukan hasil kepada siswanya yakni pada observasi kedua guru memberitahukan hasil tugas yang didapat siswa pada pertemuan sebelumnya dan pada observasi ketiga guru mengumumkan hasil ulangan harian kepada siswa yang dilaksanakan pada hari jum'at 22 mei 2015. Sesuai penuturan guru mata pelajaran sosiologi itu sendiri bahwa hasil yang didapat siswa tidak hanya diberitahukan kepada siswa tersebut namun juga diberitahukan kepada orang tua masing-masing agar mengetahui perkembangan anaknya. 
Dengan mengetahui hasil pekerjaaan, apalagi kalau terjadi kemajuan akan mendorong siswa untuk lebih giat belajar. Semakin mengetahui bahwa grafik hasil belajar meningkat, maka ada motivasi pada diri siswa untuk terus belajar, dengan suatu harapan hasilnya terus meningkat. Menurut Mulcahy (dalam Muhibbin Syah, 2012:200) "Dengan mengetahui taraf kemampuan dan kemajuan dirinya sendiri, siswa memiliki self-consciousness, kesadaran yang lugas mengenai eksistensi dirinya, dan juga metacognitive, pengetahuan yang benar mengenai batas kemampuan akalnya sendiri".

Selanjutnya dalam aspek menyampaikan tujuan pembelajaran, selama pengamatan peneliti melihat bahwa guru sosiologi tidak selalu menyampaikan tujuan pembelajaran terlebih dahulu setiap sebelum memulai menyampaikan materi pelajaran kepada siswa. Hanya pada pertemuan ketiga setelah diadakan ulangan harian, peneliti melihat guru menyampaikan tujuan pembelajaran terlebih dahulu sebelum menyampaikan materi pelajaran. Guru mata pelajaran sosiologi pun mengatakan hanya menyampaikan tujuan pembelajaran pada pertemuan pertama atau pada bab pertama saja, namun pada pertemuan selanjutnya terkadang tidak disampaikannya lagi. Padahal dengan selalu menyampaikan tujuan pembelajaran, siswa bisa mengetahui manfaat dan kegunaan mempelajari materi yang akan dipelajari. Dengan mengetahui manfaat tersebut, siswa akan termotivasi untuk mempelajarinya.

Sebagaimana menurut Hamalik (2013), "bahwa rumusan tujuan pembelajaran sekhusus mungkin, operasional dan dapat diamati karena akan mendorong siswa untuk mencapainya". Jadi pada dasarnya para siswa memiliki harapan-harapan tertentu setelah menyelesaikan pelajaran atau tugas.

Berdasarkan paparan hasil observasi dan hasil wawancara di atas, diketahui bahwa secara umum guru mata pelajaran sosiologi belum memotivasi belajar siswanya dengan maksimal. Yakni dalam hal pemberian angka dan perumusan tujuan pembelajaran yang belum dilakukan dengan secara maksimal.

Keberhasilan belajar siswa di samping ditentukan oleh faktor-faktor internal juga turut dipengaruhi oleh faktor-faktor eksternal. Faktor eksternal adalah segala faktor yang ada di luar diri siswa yang memberikan pengaruh terhadap motivasi belajar siswa.

Menurut Aunurrahman (2009:188195), ada beberapa faktor yang mempengaruhi proses belajar siswa, yakni:

\section{a) Faktor Guru}

Dalam proses pembelajaran, kehadiran guru masih menempati posisi penting meskipun di tengah pesatnya kemajuan teknologi yang telah merambah ke dunia pendidikan. Parkey (dalam Aunurrahman, 2009:189), bahwa guru tidak hanya sekedar sebagai guru di depan kelas, akan tetapi juga sebagai bagian dari organisasi yang turut serta menentukan kemajuan sekolah bahkan dimasyarakat.

Peneliti melihat bahwa guru sosiologi sering terlambat masuk kelas untuk mengajar, terkadang hingga 10-15 menit, sehingga sebelum guru mata pelajaran sosiologi masuk siswa lebih memilih keluar kelas, seperti ke kantin, duduk-duduk di teras kelas dan ada juga siswa yang ribut di dalam kelas tanpa diawasi guru. Hanya pada saat diadakan ulangan harian guru datang tepat waktu. Hal ini sesuai dengan penuturan guru mata pelajaran sosiologi itu sendiri bahwa terkadang 
tidak masuk kelas untuk mengajar sebagaimana mestinya dikarenakan banyak tugas yang harus dikerjakan di ruangan. Beliau juga mengatakan walaupun tidak masuk kelas untuk mengajar tetapi selalu memberikan tugas yang harus dikerjakan oleh siswa dan harus dikumpulkan pada hari itu juga. Selama pengamatan, peneliti juga melihat dari metode mengajar guru lebih sering menggunakan metode ceramah dan ditambah lagi suara guru yang tidak lantang, sehingga banyak siswa tidak mengerti apa yang disampaikan dan terlihat bosan saat mengikuti pelajaran seperti malas mencatat, mendengar dan memperhatikan, tidak jarang mereka memilih tiduran, mengganggu teman, bermain hp saat guru sedang menjelaskan. Sebenarnya jika guru menggunakan metode mengajar yang bervariasi akan membuat siswa tidak bosan dan jemu saat proses belajar mengajar.

b) Lingkungan Sosial (Teman Sebaya)

Sebagai makhluk sosial maka setiap siswa tidak mungkin melepaskan dirinya dari interaksi dengan lingkungan, terutama sekali temanteman sebaya di sekolah. Lingkungan sosial dapat memberikan pengaruh positif dan dapat pula memberikan pengaruh negatif terhadap siswa. Menurut Muhibbin (2009:152), bahwa lingkungan sekolah seperti para guru, para staf administrasi dan teman-teman sekelas dapat mempengaruhi semangat belajar seorang siswa. Menurut penuturan guru mata pelajaran sosiologi jika ada siswa yang sebelumnya fokus memperhatikan saat sedang menjelaskan materi, namun setelah diajak teman sebelah ngomong, maka jadi terpengaruh ikutan ngomong, ikut-ikutan mengganggu teman lain yang sedang belajar, dan ada yang suka membuat keributan di dalam kelas sehingga mengganggu konsentrasi belajar siswa lain yang sungguh-sungguh ingin belajar. Peneliti juga melihat bahwa siswa yang duduk di belakang dan terlepas dari pantauan guru di depan kelas yang sering mengganggu temannya saat belajar.

\section{c) Kurikulum Sekolah}

Dalam rangkaian proses pembelajaran di sekolah, kurikulum merupakan panduan yang dijadikan guru sebagai kerangka acuan untuk mengembangkan proses pembelajaran. Seluruh aktivitas pembelajaran, mulai dari penyusunan rencana pembelajaran, pemilihan materi pembelajaran, menentukan pendekatan dan strategi/metode, memilih dan menentukan media pembelajaran, menentukan teknik evaluasi, semuanya harus berpedoman pada kurikulum. Hal ini sejalan dengan pendapat Hamalik (2013:17), "kurikulum adalah suatu program pendidikan yang disediakan untuk membelajarkan siswa".

Pada dasarnya sekolahan ini sudah menggunakan kurikulum 2013 sejak tahun 2013 yang lalu. Karena sekolah ini menjadi sekolahan yang terpilih sebagai salah satu sekolahan yang menggunakan kurikulum 2013. Sejauh ini penerapan kurikulum 2013 sudah berjalan dengan baik, bisa dilihat dari buku paket yang dibagikan kepada setiap siswa. Guru sosiologi pun mengatakan tidak ada masalah dengan perubahan kurikulum saat ini terhadap proses pembelajaran siswa. Namun saat pengamatan guru mata pelajaran sosiologi selalu menggunakan metode mengajar yang monoton yakni metode ceramah dan tanya jawab. Padahal pada kurikulum 2013 guru hanya sebagai 
fasilitator dan pengarah, siswa lebih dituntut untuk belajar sendiri misalnya dengan kerja kelompok dan persentasi di kelas.

\section{d) Sarana dan Prasarana}

Sarana dan prasarana pembelajaran merupakan faktor yang turut memberikan pengaruh terhadap hasil belajar siswa. Keadaan gedung sekolah dan ruang kelas yang tertata dengan baik, ruang perpustakaan sekolah yang teratur dan sebagainya. Berdasarkan hasil pengamatan, masih banyak yang kurang baik dari sarana dan prasarana yang ada. Kursi dan meja banyak yang kurang layak seperti kayu yang tidak utuh, kipas angin yang tidak dapat difungsikan, plafon yang agak rusak sehingga kurang enak dilihat, sirkulasi udara yang kurang baik, ditambah lagi lokasi kelas dekat dengan WC, sehingga tidak jarang bau yang menyengat mengganggu konsentrasi siswa saat proses pembelajaran. Dengan kendala kelas yang seperti ini ketidaksediaan sarana dan prasarana pembelajaran berdampak terhadap terciptanya iklim pembelajaran yang kurang kondusif. Sesuai dengan penuturan guru mata pelajaran sosiologi bahwa keadaan kursi yang kurang baik, pentilasi yang kurang dan ada 2 buah kipas angin namun tidak bisa difungsikan secara maksimal, apalagi ditambah cuaca yang panas dan proses pembelajaran di atas jam 10-an akan membuat guru lebih ekstra dalam memberikan motivasi kepada siswa.

Hal ini sesuai dengan pendapat Muhibbinsyah (2009:153), bahwa gedung sekolah dan letaknya, alat-alat belajar, keadaan cuaca dan waktu belajar yang digunakan siswa merupakan faktor-faktor yang turut menentukan tingkat keberhasilan belajar siswa. Oleh karena itu sarana dan prasarana menjadi bagian penting untuk dicermati dalam upaya mendukung terwujudnya proses pembelajaran yang diharapkan.

Dari paparan di atas dapat diketahui bahwa ada beberapa faktor yang menjadi kendala pelaksanaan pemberian motivasi oleh guru dalam proses pembelajaran. Terutama faktor guru mata pelajaran sosiologi yang selalu terlambat masuk kelas dan selalu menggunakan metode mengajar yang monoton kemudian suara guru mata pelajaran sosiologi yang tidak lantang saat menyampaikan materi pelajaran. Hal ini tentu membuat siswa bosan mengikuti pelajaran serta tidak terkontrol dengan baik saat belajar di dalam kelas. Lingkungan sosial siswa pun juga menjadi pengaruh besar terhadap motivasi belajarnya. Apalagi ditambah dengan sarana dan prasarana yang kurang mendukung kenyamanan siswa saat proses pembelajaran berlangsung.

Menurut Sardiman (2008:45), "tanggapan adalah gambaran/bekas yang tinggal dalam ingatan setelah orang melakukan pengamatan". Tanggapan itu akan memiliki pengaruh terhadap perilaku belajar setiap siswa. Apabila siswa termotivasi dengan baik dalam proses pembelajaran, maka akan muncul tanggapan-tanggapan tentang apa yang telah mereka dapat saat belajar.

Dalam hal pemberian angka/penilaian AA, KR dan SM menuturkan bahwa guru memberikan angka/penilaian melalui pertanyaan lisan yang diberikan, menjawab soal di LKS dengan benar. Sedangkan AM, MR dan RG juga mengatakan bahwa guru sosiologi memberikan angka kepada siswa, namun mereka tidak pernah mendapatkan nilai tersebut 
dengan alasan malas untuk menjawab, malu, dan tidak percaya diri.

Kemudian dalam hal memberi hadiah / pujian AA mengatakan guru mata pelajaran sosiologi tidak pernah memberikan hadiah, tapi kalau pujian pernah karena saya mendapatkan nilai tuntas saat ulangan harian. KR juga menambahkan kalau ibu pernah memberikan pujian karena tugas yang dikerjakannya mendapat nilai baik. Begitu juga dengan SM, bahwa guru mata pelajaran sosiologi memberikan pujian kepadanya ketika dia mendapatkan nilai baik saat ulangan. Sedangkan AM, MR dan RG mengatakan tidak pernah mendapatkan pujian dari guru sosiologi.

Selanjutnya dalam hal memberikan ulangan, AA, AM, KR, MR, RG dan SM mengatakan kalau guru sosiologi selalu memberikan ulangan untuk setiap materi yang sudah selesai dipelajari.

Dalam hal memberitahukan hasil yang didapat, AA, AM, KR, MR, Gani dan Sita menuturkan bahwa guru sosiologi selalu memberitahukan hasil yang didapat baik dari hasil tugas maupun ulangan.

Kemudian dalam hal tujuan yang diakui, AA, KR, MR dan SM mengatakan bahwa guru sosiologi jarang, hanya sekali-sekali saja menyampaikan tujuan mempelajari materi yang akan disampaikan, biasanya langsung menyampaikan materi pelajaran, kecuali pada bab selanjutnya biasanya disampaikan terlebih dahulu. Sedangkan AM dan RG mengatakan guru sosiologi tidak pernah menyampaikan tujuan mempelajari materi yang akan disampaikan.

Dalam hal kehadiran guru dan metode mengajar, AA menuturkan bahwa guru sosiologi selalu hadir namun terkadang terlambat masuk. Sedangkan cara mengajar ibu kadang kurang dimengerti karena suara ibu terlalu kecil sehingga kurang jelas. AM juga mengatakan kalau guru sosiologi sering masuk terlambat. Ketika menyampaikan materi kurang dimengerti, sehingga saya malas mengikuti pelajaran. Kemudian KR mengatakan ibu terkadang tidak masuk atau terlambat masuk kelas. Ketika mengajar kurang dimengerti, bahasanya kurang dipahami. Beda dengan MR, ia mengatakan Ibu selalu hadir, namun pernah juga tidak masuk. Mengenai penyampaian materi, bisa dimengerti. RG mengatakan Ibu selalu hadir namun juga terkadang telat masuk. Dan saya jarang mengerti apa yang disampaikan guru, karena suaranya kurang jelas. Kemudian SM juga mengatakan yang sama kalau guru sosiologi selalu hadir dan saat Ibu menyampaikan materi, saya kurang mengerti karena suara ibu terlalu kecil sehingga kurang jelas.

John W. (2011:510), mengatakan bahwa motivasi murid di kelas berkaitan dengan alasan dibalik perilaku murid dan sejauh mana perilaku mereka diberi semangat, punya arah dan dipertahankan dalam jangka lama. Jika murid tidak mendengar, tidak mencatat, tidak menyelesaikan tugas karena bosan, maka dia kekurangan motivasi.

Berdasarkan paparan di atas dapat diketahui bahwa tanggapan siswa terhadap pemberian motivasi guru pada proses pembelajaran sosiologi rata-rata siswa mengatakan bahwa guru mata pelajaran sosiologi pernah memberikan angka, memberikan pujian, memberikan ulangan, memberitahukan hasil dan tujuan yang diakui. Namun 
tidak dilakukan secara maksimal. Tanggapan dari siswa yang sangat perlu diperhatikan yakni mengenai cara guru menyampaikan materi saat di dalam kelas, siswa mengatakan kurang

\section{KESIMPULAN DAN SARAN}

\section{Kesimpulan}

Berdasarkan hasil penelitian yang telah peneliti lakukan, dapat ditarik kesimpulan bahwa Upaya Guru dalam Memotivasi Siswa pada Proses Pembelajaran Sosiologi Kelas XI IPS2 secara umum sudah dilaksanakan namun belum dilakukan dengan maksimal, seperti dalam hal pemberian angka yang tidak selalu dilakukan setiap pertemuan, dan saat mengajar gurunya tidak selalu menyampaikan tujuan pembelajaran untuk setiap materi ajar. Kendala pelaksanaan pemberian motivasi oleh guru pada proses pembelajaran sosiologi di kelas XI IPS2 yaitu faktor guru yang terkadang terlambat masuk kelas untuk mengajar, metode mengajar yang monoton dan suara guru yang kurang lantang saat menjelaskan. Lingkungan sosial (termasuk teman sebaya) yang sangat mempengaruhi motivasi belajar siswa serta sarana dan prasarana yang masih kurang baik, merupakan faktor yang turut memberikan pengaruh terhadap motivasi belajar siswa. Tanggapan siswa terhadap pemberian motivasi guru pada proses pembelajaran sosiologi di kelas XI IPS2 yaitu rata-rata siswa mengatakan bahwa guru sosiologi pernah memberikan angka, memberikan pujian, ulangan, memberitahukan hasil dan menyampaikan tujuan yang diakui. Namun belum dilaksanakan dengan maksimal. Tanggapan dari siswa yang sangat perlu mengerti tentang materi yang disampaikan oleh guru sosiologi karena volume suara guru yang tidak keras. Hal ini membuat siswa malas mengikuti pelajaran sosiologi.

diperhatikan yakni mengenai cara guru menyampaikan materi saat di dalam kelas, siswa mengatakan kurang mengerti tentang materi yang disampaikan oleh guru sosiologi karena volume suara guru yang tidak lantang.

\section{Saran}

Berdasarkan hasil pembahasan yang diperoleh, maka dapat disampaikan beberapa saran sebagai berikut: Sebaiknya guru selalu memberikan angka kepada siswa disetiap pertemuan agar siswa termotivasi belajar demi mendapatkan nilai, serta diharapkan selalu menyampaikan tujuan pembelajaran untuk setiap materi yang akan diajarkan agar siswa mengetahui manfaat mempelajari apa yang akan disampaikan. Sebaiknya guru harus selalu hadir atau masuk kelas tepat waktu saat jam mengajar agar siswa tetap terkontrol saat belajar dan diharapkan agar guru selalu bisa menyesuaikan situasi dan kondisi di dalam kelas seperti saat cuaca panas supaya siswa tetap bersemangat mengikuti pembelajaran sesuai yang diharapkan. Sebaiknya guru lebih memperhatikan intonasi suara dan melantangkan suara saat menjelaskan materi kepada siswa agar siswa memahami apa yang disampaikan, dan diharapkan selalu mengontrol siswa secara keseluruhan supaya tidak ada siswa yang tiduran, bermain HP, ngobrol, mengganggu teman lain saat proses pembelajaran berlangsung. 


\section{DAFTAR RUJUKAN}

Aunurrahman. (2009). Belajar dan Pembelajaran. Bandung : Alfabeta.

Hadari Nawawi \& Martini Hadari. (1992). Instumen Penelitian Bidang Sosial. Yogyakarta : Gajah Mada University Press.

John W. Santrock. (2011). Psikologi Pendidikan. (Dialihbahasakan oleh Tri Wibowo B.S.). Jakarta: Kencana.

Muhibbin Syah. (2012). Psikologi

Oemar Hamalik. (2013). Kurikulum dan Pembelajaran. Jakarta: Bumi Aksara.

Sardiman A.M. (2008). Interaksi \& Motivasi Belajar Mengajar. Jakarta: PT Raja Grafindo Persada.

Sugiyono. (2013). Memahami Penelitian Kualitatif. Bandung: Alfabeta.

Suharsimi Arikunto. (2010). Prosedur Penelitian Suatu Pendekatan Praktik. Jakarta: Rineka Cipta. Belajar. Jakarta: Rajawali Pers. 